\title{
Effects of International Trade on East and Southeast Asians' Views of China
}

\begin{abstract}
Alec Chung
This article aims to investigate the effects of trade on individuals' views of China. Specifically, winners and losers of trade with China - in Indonesia, Japan, Malaysia, the Philippines, South Korea, and Thailand -are expected to have different views of China. Using the Pew Research Center 2014 survey, the results of empirical analyses show that, regardless of whether they are expected to be the winners or not, educated individuals were more likely to view China as a threat to their country than the less educated. Meanwhile, although support for trade ties with other countries was positively associated with favorable opinions of China, in the upper-middle- and high-income countries, it did not particularly reduce the likelihood of viewing China as a threat. In short, although trade can foster favorable views of China among individuals in East and Southeast Asia, China can still be regarded as a threat to their country.
\end{abstract}

Key Words: China, Asia, Elite Opinion, Threat Perception, International Trade

\section{INTRODUCTION}

As of 2014, China is the second largest economy in the world, only behind the US. The unprecedented speed of rise of China has raised concerns among its neighbors on whether it will pose a threat to their national security or not. Several scholars have made or introduced the argument that China will show aggressive behaviors as its rise changes the power distribution in Asia (Al-Rodhan 2007; Mearsheimer 2006, 2010; Roy 1994, 2005).

On the other hand, there are counter-arguments among other scholars that

\footnotetext{
*Alec Chung (alecchung84@ufl.edu) is a post-doctoral researcher at the Hanyang Peace Institute, Hanyang University. He received a Ph.D. in political science from the University of Florida. His research interests include international relations, research methods, and political economy in East Asia with a particular focus on the impact of trade on relations between Asian countries.
} 
China is not a revisionist state and that its neighbors can benefit from China's rise since it also wants stability in Asia for its economic growth (Kang 2005; Shambaugh 2005). For instance, as China's economy grew at an unprecedented speed, China has become the largest trading partner to its neighbors in Asia since it acted as "an engine of export growth" (Lall and Albaladejo 2004, 1456) by absorbing other countries' exports. As Asian countries benefit more and more from economic ties with China, they will eventually face the situation in which they have to choose between either to balance against security threats posed by China or to bandwagon with it to reap the economic benefits coming from that tie (Chung 2009/2010).

Meanwhile, although Asian countries might benefit from increased trade with China at the state level, not all individuals within China's neighboring countries will benefit from trade with China. International trade is bound to create losers and winners at the domestic level, having distributional effects. As Asian countries increase their exports to China, individuals employed in industries that benefit from increased demands from China will see their income rising. On the other hand, while exports to China have increased among its neighboring countries, imports from China has also increased in its neighbors as China's economy grows, which will harm individuals working in industries and sectors that are competing with Chinese products. Under this situation, this article aims to explore whether there is a potential for achieving commercial peace in Asia by investigating how trade affects individuals' views of China. For instance, winners of trade with China - captured using the Stolper-Samuelson theorem which is one of the most widely used frameworks to study the distributive effects of trade (Baker 2005; Mayda and Rodrik 2005; Fordham and Kleinberg 2011) - are expected to have more positive views of China than those who lose.

Among China's neighbors, six Asian countries - Indonesia, Japan, Malaysia, the Philippines, South Korea, and Thailand - were chosen for the analyses due to data availability and because these countries are democracies. As of 2014, these Asian countries are democratic states, according to the Polity IV Project (Marshall and Gurr n.d.). Democracies were chosen for this study because, although still debatable, individuals have the power to constrain and influence their governments' foreign policy decisions, making individuals' views one of the primary sources of foreign policy. For instance, individuals are capable of pressuring their government since public opinion can constrain and cause changes in government policies (Page and Shapiro 1983). One reason is that the public can have stable and coherent preferences regarding issues that impact their daily lives such as concerns over jobs (Page and Shapiro 1992, 170).

From the perspective of political leaders, on the other hand, several scholars 
have argued that retaining office is the primary goal of leaders in democracies. Thus, leaders should deliver what the voters want such as economic growth (Gelpi and Grieco 2003) while also being attentive to "voter preferences" in making foreign policy decisions (Simmons 2003). For instance, Papayoanou argues that since leaders know that people who were negatively influenced by the government's decision could decide to vote against the governing party in the next election, this situation "constrains state leaders in democracies to pursue policies that are largely consistent with the median preferences of vested interests" (Papayoanou 1996, 47) rather than pursuing policies that they think is necessary for their country. Accordingly, several scholars have shown evidence that public opinions have constraining effects on foreign policy decision makers (Fordham 1998; McLean and Whang 2014; Sobel 2001).

As China's economic growth has more and more impact on these Asian countries, as shown in Figure 1 and 2, individuals' attitudes toward China can be affected depending on how they are affected by China's economic growth. These attitudes, in turn, can potentially affect their government's foreign policy decisions toward China since public opinion can constrain democratic governments' behaviors through elections.

Figure 1. Total value of trade between China and its neighbors

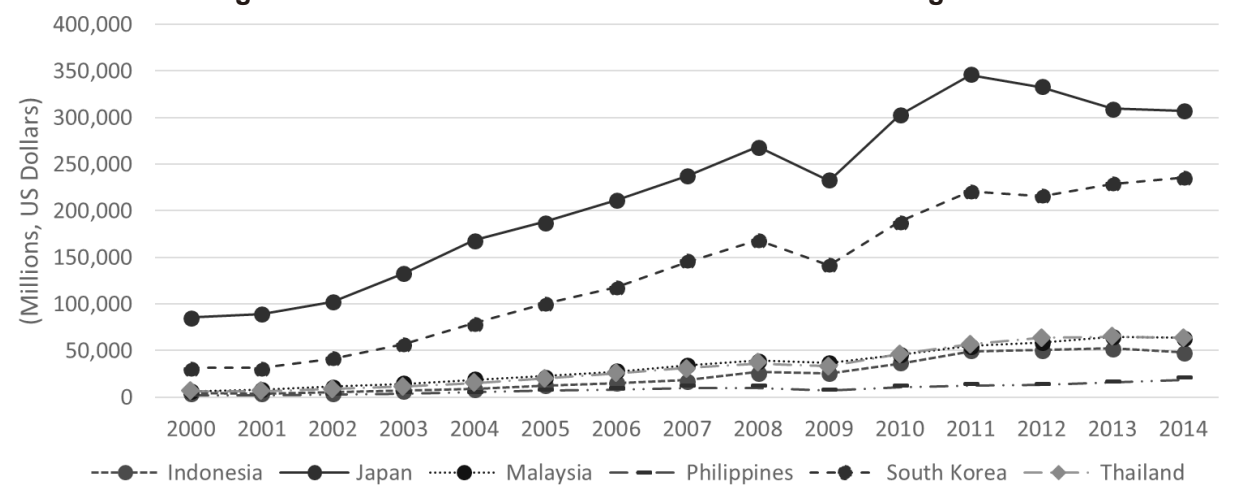

Source: Direction of Trade Statistics (DOTS) n.d. IMF eLibrary Data. Accessed at: http://data.imf.org/?sk=9D6028D4-F14A-464C-A2F2-59B2CD424B85 (January 12, 2017). 
Figure 2. Trade with China as a \% of each country's total trade

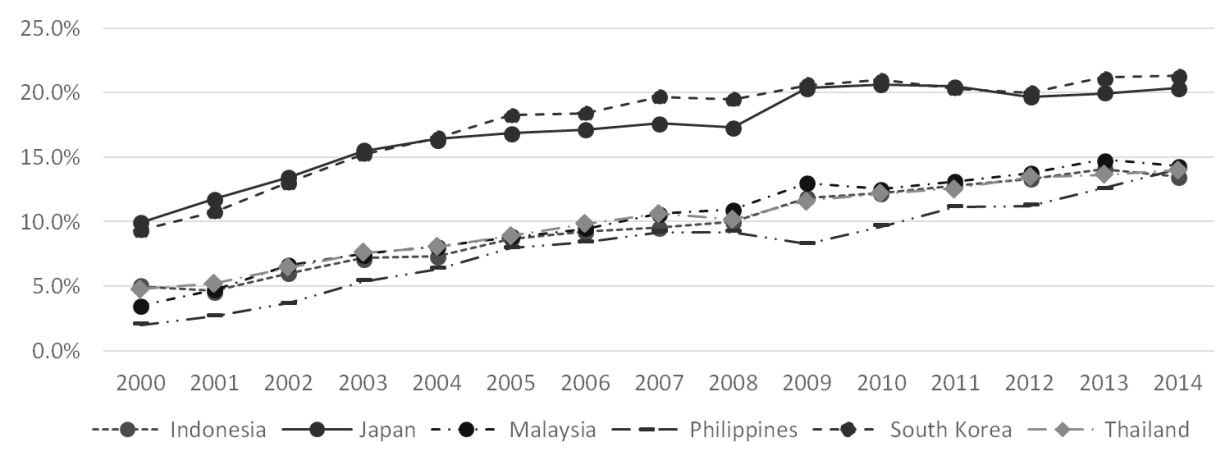

Source: Direction of Trade Statistics (DOTS) n.d. IMF eLibrary Data. Accessed at: http://data.imf.org/?sk=9D6028D4-F14A-464C-A2F2-59B2CD424B85 (January 12, 2017).

Therefore, although how individuals' economic condition is affected by China's economic growth might not be the only factor that could affect the voters' decisions in elections, it could be one of the constraints on foreign policy decisions of the governments, making individuals' attitudes an important subject that needs to be studied further.

Overall, holding all other conditions constant, the empirical results of the statistical analyses using the Pew Research Center Global Attitudes \& Trends Spring 2014 survey show that, regardless of whether they are expected to be winners or losers, Asians with at least some college education were more likely to view China as a threat to their country than those with no high school degree. Besides, while those who support international trade were less likely to have unfavorable views of China (in the upper-middle-income and high-income countries), the support did not particularly reduce the likelihood of viewing China as a threat. These results suggest that, while support for international trade promotes favorable opinions of China, it might not be enough to completely prevent individuals from viewing China as a threat to their country in the future. In other words, how individuals are affected by trade with China or whether they support international trade do not diminish individuals' concerns over their country's national security. These findings suggest that there is not enough evidence to argue that there is a potential for achieving commercial peace between China and its democratic neighbors at this stage. 


\section{TRADE BETWEEN CHINA AND ITS NEIGHBORS AND ITS DIS- TRIBUTIVE EFFECTS ON INDIVIDUALS}

The research question raised in this article is based on the commercial peace argument. The commercial peace idea argues that economic interdependence between states deters conflict and promotes peace between states by increasing the prospect of war costs (Oneal and Russett 1997; Oneal 2003; Hegre, Oneal, and Russett 2010). Since disruption of beneficial economic ties raises the cost of conflicts, states try to avoid costly conflicts such as militarized disputes as state leaders have incentives to avoid conflicts and seek a peaceful relationship between states (Levy 2003; Gartzke 2003).

Besides, this study focuses on how trade with China impacts individuals as producers. Therefore, although individuals' might benefit from trade with China as consumers of cheap goods imported from China, the focus is on how trade with China impacts individuals' economic status as producers, particularly their income, and how that affects their overall attitudes toward China.

The issue is how we can measure whether individuals benefit or lose from increased trade with China. As shown in Figure 1, overall, there has been a dramatic increase in the total value of trade conducted between China and Asian countries. Also, as shown in Figure 2, the share China occupies in its neighbors' total trade also increased annually, making China the major trading partner to these countries in Asia. Nevertheless, simply looking at the products being traded, however, does not tell us who benefits and loses from trade with China. For instance, although machinery and electrical machinery are major imports from China for Indonesia (45.6\%), Japan (45.5\%), Malaysia (52.7\%), the Philippines (33\%), South Korea (43.2\%), and Thailand (49.2\%) (UN Commodity Trade Database n.d.), the role China is playing is processing trade which China uses its cheap labor force to assemble the intermediate goods imported from countries like Japan and South Korea (Chiang 2013). Although China looks like it is exporting high-tech products, according to the UN Commodity Trade data, it is exporting "processed/assembled high-tech" products which require lowskilled workers (Xing 2011, 1). Thus, it is Chinese low-skilled workers who are benefiting from China exporting machinery and electrical machinery while those low-skilled workers in other countries such as Japan and South Korea are being harmed (such as by losing their jobs or seeing their income decrease) due to its firms losing shares in the global market. On the other hand, high-skilled workers with human and financial capitals from foreign developed countries are the ones who make investments in China and benefit from trade with China. In short, an analytical framework that provides a more detailed explanation of who benefits 
or loses in international trade is necessary.

One of the widely used frameworks is the Stolper-Samuelson theorem which predicts the distributive effects of international trade according to factor endowments that are relatively abundant or scarce in a country. When two countries with different factor endowments engage in trade, both countries export goods that are associated with factors that are relatively abundant in them while importing goods intensive in factors that are relatively scarce (Frieden and Rogowski 1996). For instance, a country relatively abundant in unskilled labor will export labor-intensive, low-technology goods that require low-skilled workers who earn low wages. On the other hand, a country relatively abundant in skilled workers will export high-technology goods (or services which is not included in the Stolper-Samuelson theorem) while importing low-technology goods from other countries. Based on this theorem, at the individual level, the Stolper-Samuelson theorem expects that individuals who are associated with factors that are relatively abundant in their country will benefit from international trade as their income will rise while those who are associated with relatively scarce factors will lose from trade with other countries.

The Stolper-Samuelson theorem, however, provides no explanation on how countries with similar factor endowments trade with each other (Kleinberg and Fordham 2010, 691) which is its limits. For instance, the Stolper-Samuelson theorem will expect that skilled workers and owners of capital in Japan, which is a capital abundant, high-income economy according to the World Bank (World Bank Country and Lending Groups n.d.), will benefit from trade with China, which is an upper-middle-income economy abundant in unskilled labor. On the other hand, the Stolper-Samuelson theorem does not explain who will benefit from trade among China, Malaysia, and Thailand that are all upper-middleincome economies (World Bank Country and Lending Groups n.d.). Besides, unlike what is expected by the theorem, some studies have shown that, despite the cross-national differences in the distribution of factor endowments, highskilled workers are more likely to support free trade with other countries than low-skilled workers, even in low-skilled labor-abundant countries (Baker 2005; Beaulieu et al. 2005).

Despite the limits, the Stolper-Samuelson theorem has been widely used to identify who are the beneficiaries of trade and who are not (Baker 2005; Mayda and Rodrik 2005; Fordham and Kleinberg 2011) since it can be applied on survey data more easily (by using individuals' education and income levels as proxies of whether they are high-skilled workers or owners of financial capital) than the alternatives such as the Ricardo-Viner model. According to the model, relative competitiveness of sectors determines who benefits and loses from trade 
with other countries not that it depends on relative abundance or scarceness of factors in that country (Frieden and Rogowski 1996, 38). For instance, while the Stolper-Samuelson theorem predicts that high-skilled workers in a relatively human-capital-abundant country will benefit from trade with a relatively unskilled-labor-abundant country, the Ricardo-Viner model expects that highskilled workers employed in sectors that are competitive in the world market are the ones who benefit from trade with other countries. Moreover, those who benefit from international trade are the ones who have specific skills that allow them to compete in the world market, not that high-skilled workers in skilledlabor-abundant countries, in general, benefit from trade with unskilled-laborabundant countries. For instance, unlike what the Stolper-Samuelson theorem had predicted, not all high-skilled workers and those with capital in developed countries like Japan will see their income increase through trade with China. Instead, it will be those who are working in particular industries such as the Japanese automobile industry who will gain since it is industry competitive in the world market.

However, although researchers can use individuals' occupation (Baker 2005) in addition to their education level and income to measure their skill level, surveys rarely ask specific questions regarding which industry or sector respondents are employed, making it impossible to test the Ricardo-Viner framework using survey data. For instance, although the Asian Barometer Survey (2010-2012) asked questions such as whether respondents are high service, low service, skilled manual, or unskilled manual workers, information regarding respondents' specific industry of employment cannot be obtained in the dataset. This is one of the main reasons scholars continue to rely on the Stolper-Samuelson framework when using surveys to conduct empirical analyses instead of applying the Ricardo-Viner framework to capture winners and losers of international trade.

As mentioned above, six Asian countries were chosen to conduct empirical analyses. The World Bank (Country and Lending Groups n.d.) classifies countries into four categories depending on each country's Gross National Income (GNI) per capita - low-income economies (US\$1,005 or less), lowermiddle-income economies (US\$1,006 to US\$ 3,955), upper-middle-income economies (US\$ 3,956 to US\$12,235), and high-income economies (US\$12,236 or more). Kleinberg and Fordham (2010) used this World Bank's classification to determine whether each country's factor endowments are abundant or scarce relative to others. Thus, according to the World Bank, Indonesia and the Philippines are lower-middle-income economies. Malaysia and Thailand are the upper-middle-income economies while China also belongs to this category. 
Finally, Japan and South Korea are high-income economies. Therefore, the Stolper-Samuelson theorem will expect that unskilled and low-income workers in Indonesia and the Philippines will benefit from trade with China (which is a relatively capital-abundant country than these countries) since their wages are lower than in China (See A tightening grip 2015). For instance, in 2013, the average monthly wage was US\$ 183 in Indonesia and US\$ 215 in the Philippines, according to the International Labor Organization (ILO) (Global Wage Report 2014/2015). The numbers were significantly lower than in China where the average monthly wage was US\$ 613 . On the other hand, skilled workers and high-income workers in Japan and South Korea will gain from trade with China which is, in this case, a relatively capital-scarce and labor-abundant country. The average monthly wage was US\$ 3,320 in Japan and US\$ 2,841 in South Korea, according to the ILO. Since the labor cost in China is significantly cheaper than in these high-income countries, low-skilled and low-income workers in Japan and South Korea are less competitive in the global market than those in China.

Meanwhile, as mentioned above, the Stolper-Samuelson theorem does not make any predictions regarding how trade impacts countries that share similar factor endowments. Thus, the theorem does not offer predictions regarding how attitudes of skilled and unskilled workers in Malaysia and Thailand will be impacted by trade with China if we continue to employ the World Bank's classification of economies. Still, the average monthly wage was US\$ 651 in Malaysia and US\$ 391 in Thailand, according to the ILO, even though World Bank grouped them in the same category. Thus, based on this information, the Stolper-Samuelson theorem will expect low-skilled workers in Thailand to benefit from trade with China (where labor costs are higher) while skilled workers are in a disadvantage (since China is the relatively capital-abundant country in this case) On the other hand, it is still difficult to predict who wins or loses in trade between China and Malaysia since the average monthly wages of the two countries were almost the same (US\$ 613 and $\$ 651$, respectively).

\section{RESEARCH DESIGN}

For the empirical analyses, the Pew Research Center Global Attitudes \& Trends Spring 2014 survey data was used to test how individuals' educational attainment and income level impact their view of China as a threat. The original Pew Research Center dataset contained 48,643 respondents from 44 countries across the world. Since the scope of this study is China's neighbors that are democracies, only 6,019 respondents from six Asian countries are included in 
the analyses.

\section{DEPENDENT VARIABLE}

The dependent variable in the empirical analyses using the Pew Research Center data is whether individuals think China will be the country which will pose the greatest threat to their country in the future (Q96b). A value of one is assigned to those who answered that China will be the biggest threat to their country while a value of zero is assigned to those who answered other countries or none.

Table 1. Q96b. What countries or groups pose the greatest threat to (survey country) in the future?

\begin{tabular}{lllll}
\hline & $\begin{array}{l}\text { China poses a } \\
\text { greatest threat } \\
\text { in the future (\%) }\end{array}$ & Others (\%) & $\begin{array}{l}\text { Don't know/ } \\
\text { Refused (\%) }\end{array}$ & $\mathbf{n}$ \\
\hline Indonesia & 24.10 & 52.10 & 23.80 & 1,000 \\
Japan & 76.60 & 16.10 & 7.30 & 1,000 \\
Malaysia & 12.08 & 40.59 & 47.33 & 1,010 \\
South Korea & 54.01 & 43.81 & 2.18 & 1,009 \\
Thailand & 5.80 & 49.40 & 44.80 & 1,000 \\
The Philippines & 68.65 & 21.43 & 9.92 & 1,000 \\
\hline
\end{tabular}

As shown in Table 1, the percentages of viewing China as one of the biggest threats to their country varied widely among countries, ranging from $5.8 \%$ (Thailand) to $76.6 \%$ (Japan). While $12.08 \%$ of Malaysians, $24.1 \%$ of Indonesians, and $54.01 \%$ of South Koreans viewed China as a threat, the percentage was 68.65 among Filipinos.

As shown in Table 1, the negative attitudes toward China were highest in Japan compared to other countries. This result seems to suggest that the prevailing view among Japanese is that China has become a regional rival which threatens Japan's status as a regional power which it maintained for decades since the Cold War era. After all, Japan and China have been sensitive to each other's actions throughout the years having a possibility of "plunging Asia into a new Cold War" (Roy 1994, 150).

\section{INDEPENDENT VARIABLES}

The main independent variables of interest for the first round of empirical analyses using the Pew Research Center data are individuals' education (Q138) and income level (Q149).

As mentioned above, individuals' education level has been widely used as a proxy for their skill level, identifying respondents as skilled or unskilled workers. Since China is a relatively labor-abundant/capital-scarce country considering 
the size of its population, it is expected that low-skilled workers in high-income countries such as Japan and South Korea will be harmed while high-skilled workers in those countries will benefit from the economic tie with China. On the other hand, unskilled and low-wage workers in countries that are capital-scarce than China such as Indonesia and the Philippines (and Thailand) will see their income increase due to trade with China. In contrast, skilled workers in these low-income economies will be harmed by trade with China which is a capitalabundant country from their position. In short, how individuals are likely to be impacted economically will shape their perceptions of viewing China negatively or not.

Regarding education levels, response categories varied by country, so the responses were re-categorized into three levels - less than high school degree, high school degree or equivalent, and at least some college education - to make the number of respondents almost equal in each category. In the statistical analyses, the "less than high school degree" will be used as a base while the other two levels will be included as dummy variables.

Income can also be used as a proxy of whether individuals are owners of financial capital in abundance or not, providing another way to test whether there is evidence for the Stolper-Samuelson theorem. Again, high-income individuals in high-income countries are expected to have less negative views of China which is an upper-middle-income country while those in the low-income countries will have more negative views of China. In contrast, low-income individuals from high-income countries will have more negative views of China than those in low-income countries since China will have a different economic impact on the countries in two different categories.

In the Pew Research Center data, response categories for income also varied by country, so the responses were categorized into four levels - lower 0-25\%, lower 26-50\%, upper 51-75\%, and upper 76-100\%. In the statistical analyses, the "lower 0-25\%" category will be used as a base while the other levels will be included as dummy variables.

\section{CONTROL VARIABLES}

Gender (Q132), age (Q133), the perception of the impact China's economic growth has on a respondent's country, (Q108), a concern over territorial disputes between China and its neighbors (Q110), and whether the US is a dependable ally (Q96a) are used as control variables.

For gender, male is coded as one while female is coded as zero. Trade could have a different impact on individuals depending on their gender (Ozler 2000). Particularly, women's employment opportunities can be affected as increased 
export leads to increased job opportunities for female workers. Since the employment of Asian women can be impacted by trade with China, gender can affect individuals' attitudes of China which makes it necessary to be controlled. Age can also affect individuals' attitudes of other countries such as China. The older generation in China's neighbors might have a more hostile view of China, which was an enemy state during the Cold War era, than young individuals who have no such memory.

The perception of China's economic impact will be used to control the effect of individuals' perception, not their education and income level, on shaping their view of China as a threat or not. Individuals in China's neighboring countries might not be sure how they are economically impacted by China's economic growth and increased trade with China. Since not all individuals will have the information on how trade with China impacts them, the perception of how individuals think they are being impacted has the potential to affect their views of China. Therefore, it is necessary to separate the effects of individuals' perception and the effects of their education and income levels to test the Stolper-Samuelson theorem more directly.

The Pew Research Center survey includes a question asking whether individuals think China's economic growth is a good thing to their country or not (Q108). A value of one is assigned to those who perceive China's economic growth as a good thing to their country while zero is assigned to those who said it is a bad thing.

Other than variables related to the economic impact China can have on individuals' economic conditions, there are other concerns that can affect their views toward China. Although China is its neighbors largest trading partner, there are also conflicts between China and its neighbors that could seriously damage the political relations while increasing fears among Asians in the region. For instance, concerns over whether territorial disputes between China and its neighbors could lead to military conflicts have the potential to influence respondents' attitudes of China. The level of concerns shown by respondents have four categories - a value of one is assigned to "not at all concerned" while a value of four is assigned to "very concerned." In the statistical analyses, the "not at all concerned" will be used as a base category while the other three levels will be included as dummy variables.

Specifically, there have been territorial disputes over the Senkaku/Diaoyu Islands between China and Japan (see Troubled skies over troubled waters 2015; Tamkin 2016) and territorial disputes over Socotra Rock in the Yellow Sea between China and South Korea (see Tiezzi 2015). Also, since the 1990s, China has shown aggressive actions in the South China Sea, attempting to 
extend and consolidate its claim in the region which led to escalated tensions with its neighbors such as Brunei, Indonesia, Malaysia, the Philippines, Taiwan, and Vietnam (see Storey 1999; Rowan 2005; Fravel 2011) who also have their own claims regarding the region. With the growth of its naval strength, accompanied by a surge of nationalism, China has shown expansive intentions in the South China Sea, which could damage the relationship between China and its neighbors that have overlapping claims over the region (see Yahuda 2013). Thus, individuals who think China is posing a threat that could lead to military conflicts are expected to have more negative attitudes of China.

Finally, a dummy variable of whether respondents regard the US as a dependable ally in the future is also included as a control variable. With ongoing territorial disputes with China, China's neighbors might try to maintain close ties with the US for security reasons. For instance, Southeast Asian countries including Indonesia, Malaysia, and the Philippines are showing balancing behaviors against China, which is a rising regional power, while Thailand is showing a hedging behavior maintaining ties with both China and the US (Roy 2005). Meanwhile, Japan and South Korea have been military allies with the US for more than a half-century since the Cold War era. As shown, countries in East and Southeast Asia are maintaining a close relationship with the US which can provide assistance so they can balance against the rising regional power when necessary. Under this situation, individuals could think they are in a situation which their country has to choose either to maintain a close tie with China for economic benefits or with the US for security reasons. Among individuals in China's neighbors, those who think the US is a dependable ally and that their country should maintain a close tie with the US will be more likely to view China as a threat in the future, believing that it is necessary for their country to balance against China.

\section{EMPIRICAL ANALYSES}

Considering the nature of the dependent variable, which is dichotomous, logistic regression model will be used for analyses. For empirical analyses, six countryspecific models will be estimated to test whether there are cross-national differences regarding the association between the main independent variables of interest and the dependent variable. For all the models, the probability weights of individuals are used to take into account their probability of being sampled. Besides, among the responses, "don't know" and "refused to answer" are all excluded from the analyses. 
Effects of International Trade on East and Southeast Asians'Views of China $\mid 171$

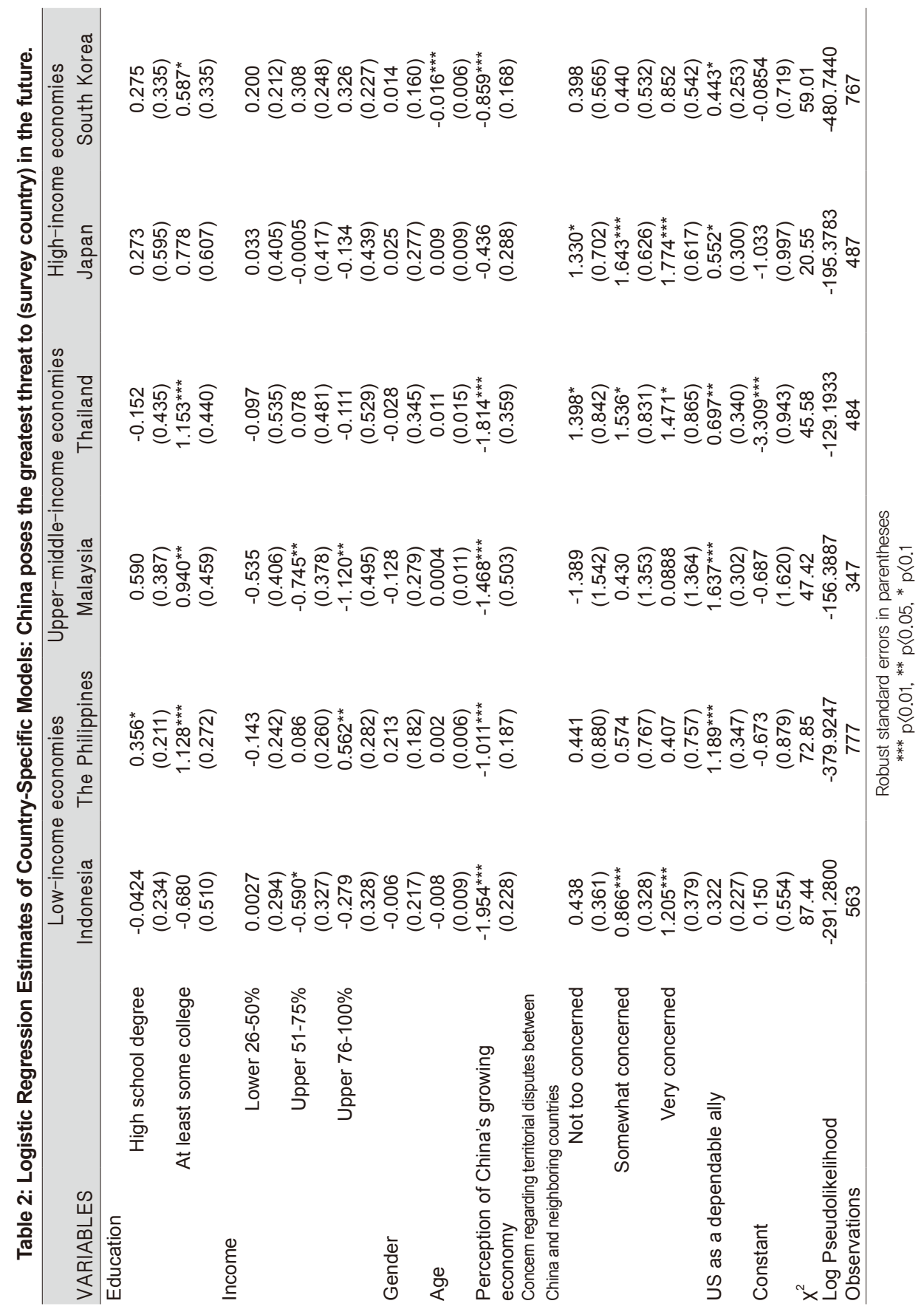


As shown in Table 2, examining the attitudes of individuals from low-income countries first, the results of the Indonesian model show that education levels do not have any statistically significant impact on Indonesians' view of China, unlike what was predicted by the Stolper-Samuelson theorem. As for the income level, while individuals in the upper 51-75\% income level were less likely to view China as a threat than the lowest class $(\mathrm{p}<0.1)$, holding other variables constant, those in the highest income level did not show statistically significant result, although they were also less likely to have negative views of China. Positive perception of China's economic growth, on the other hand, were negatively associated with viewing China as a threat as expected ( $p<0.01)$, holding all other variables constant. Although Indonesians who are "somewhat" and "very concerned" about territorial disputes between China and its neighbors leading to a military conflict were more likely to view China as a threat ( $\mathrm{p}<0.01$ for both responses) than those who are "not at all concerned," holding all other variables constant, they did not necessarily view the US as a dependable partner to their country.

In the Philippines, individuals with high school degree and at least some college education were more likely to view China as a threat ( $\mathrm{p}<0.1$ and $\mathrm{p}<0.01$, respectively) than those without high school degree, holding all other variables constant, as expected by the Stolper-Samuelson theorem. On the other hand, those in the upper $76-100 \%$ income level were more likely to view China as a threat $(\mathrm{p}<0.05)$ than those on the lowest income level, holding all other variables constant. Since high-income individuals in a low-income country will be harmed by trade with a capital-abundant country, these Filipinos will have negative attitudes toward China. Still, even in the Philippines, the perception of China's growing economy as a good thing to their country was negatively associated with viewing China as a threat $(\mathrm{p}<0.01)$, holding all other variables constant. Finally, respondents who see the US as a dependable ally were more likely to view China as a threat $(\mathrm{p}<0.01)$, holding all other variables constant, while their concerns over territorial disputes between China and its neighbors did not show statistically significant associations.

As for the attitudes of individuals from high-income countries, education and income levels showed no association with how respondents viewed China in Japan, failing to provide empirical support for the Stolper-Samuelson theorem that high-skilled workers will benefit and have positive attitudes toward China while low-skilled workers will lose and have negative views of China. Meanwhile, viewing China's economic growth as a good thing to Japan was not associated with viewing China as a threat to their country or not, holding all other variables constant. It turns out that Japanese are the only people which a positive view of 
China's economic growth did not lead to less a negative view of China. Japanese who are "not too concerned," "somewhat concerned," and "very concerned" about territorial disputes between China and neighboring countries, on the other hand, were more likely to view China as a threat ( $<<0.1, p<0.01, p<0.01$, respectively) than those who are "not at all concerned," holding all other variables constant. Overall, Japanese view China as one of the biggest threats to their country more than individuals in other Asian countries, which is also shown in Table 1 (76.60\% of Japanese thought China poses the greatest threat in the future). Again, the prevailing view among Japanese seems to be that China has become a regional rival which threatens Japan's status as a regional power which it maintained for decades since the Cold War era.

In the South Korea model, those with at least some college education were more likely to view China as a threat $(\mathrm{p}<0.1)$ than those with less than secondary education, holding all other variables constant, while the income level had no effects. Again, the Stolper-Samuelson theorem failed to predict the result. According to the theorem, high-skilled workers in a capital-abundant country will benefit from trade with a capital-scarce and labor-abundant country. However, as the result showed, high-skilled South Koreans were more likely to have negative attitudes of China, providing no empirical support for the theorem. On the other hand, the perception of China's economic growth as a good thing to South Korea was strongly associated with viewing China as not a threat $(\mathrm{p}<0.01)$, holding all other variables constant. Among other control variables, South Koreans were not concerned about territorial disputes between China and its neighbors while those who view the US as a dependable ally were more likely to view China as a threat $(\mathrm{p}<0.1)$, holding all other variables constant.

For individuals from the upper-middle-income countries, the Malaysia model showed that those with at least some college education were more likely to view China as a threat $(\mathrm{p}<0.05)$, holding all other variables constant. On the other hand, those in the upper $51-75 \%$ and upper $76-100 \%$ income level were less likely to view China as a threat compared to the lowest class ( $\mathrm{p}<0.05$ ), holding all other variables constant. Furthermore, those who view China's economic growth as a good thing to their country were less likely to view China as a threat $(p<0.01)$, holding all other variables constant. On the other hand, concerns over territorial disputes involving China and its neighbors did not affect Malaysians' view of China while viewing the US as a dependable ally were positively associated with perceiving China as a threat $(\mathrm{p}<0.01)$, holding all other variables constant.

Finally, in Thailand, while the income levels had no significant association with their views of China, Thais with at least some college education were more likely to have a negative perception of China compared to those with less than 
high school education ( $\mathrm{p}<0.01)$, holding other variables constant. Respondents were less likely to perceive China as a threat when they think China's economic growth is a good thing to Thailand ( $\mathrm{p}<0.01$ ), holding all other variables constant. Also, although the associations were weak, respondents who are "not too concerned," "somewhat concerned," and "very concerned" about territorial disputes between China and its neighbors were more likely to view China as a threat ( $<<0.1$ for all the categories) than those who were "not concerned at all," holding all other variables constant. Viewing the US as a dependable ally also increased the likelihood of perceiving China as a threat ( $\mathrm{p}<0.05)$, holding other variables constant.

As shown above, while more educated individuals from the Philippines were more likely to view China negatively than those with less education, the same result was not shown among Indonesians, not providing enough support for the Stolper-Samuelson theorem between China and low-income economies. However, the result of the Indonesian model should be interpreted with caution since, in the sample, the percentage of Indonesians with at least some college education is relatively low (7.44\%) compared to those who graduated high school (39.13\%) and those with less education (53.42\%). Besides, even in the Philippines, which is also considered as one of the low-income economies, the percentage of individuals in the sample with at least some college education is $27.18 \%$. Thus, the small sample size of the "at least some college" category in the Indonesian model might have led to an unexpected and statistically insignificant result.

Meanwhile, although the Stolper-Samuelson theorem cannot predict how trade impacts individuals in countries that share similar factor endowments, the results in Malaysian and Thai models showed that high-skilled workers in the upper-middle-income countries showed negative attitudes toward China which is also an upper-middle-income country. Since the average monthly wages were lower in Thailand than in China, the result in the Thailand model can still be explained by the Stolper-Samuelson theorem - skilled workers in a relatively capital scarce country will be harmed by trade with a relatively capital abundant country, fostering negative views toward that country. However, Malaysian skilled workers' views toward China cannot be predicted by theorem nor by comparing the labor costs of the two countries since the average monthly wages of the two countries were approximately the same. Besides, as also shown above, high-skilled individuals from the high-income countries also showed negative attitudes toward China (although the result was not statistically significant among Japanese).

These results lead to a question of whether individuals' education level can 
be an appropriate proxy for their skill level. Scholars have raised a question of whether education level represents individuals' skill levels or whether it merely shows the level of exposure to ideas such as cosmopolitanism or free trade that are taught in college (Hainmueller and Michael Hiscox 2006). If education level represents the latter, then, not only education is not a measure of skill level, mere exposure to the idea of cosmopolitanism or free trade does not guarantee that college students will be indoctrinated by that idea. Besides, college students can also be exposed to ideas such as realism which expects the rise of China to have negative consequences to its neighbors. For instance, as mentioned above, a realist scholar such as Mearsheimer (2010) has continually argued that China cannot rise peacefully. With exposure to such ideas, more educated individuals might have increased threat perception regarding the rising power as their knowledge of international politics increases as well. For instance, Tversky and Kahneman (1983) have shown that professional analysts were likely to have high estimates of threat probability since they have knowledge of possible scenarios and feasible outcomes. Therefore, the results shown in Table 2 indicates that regarding individuals' education level as representing their skill level might be a too simplified assumption.

As for the income level, only in Malaysia were the individuals in the highest income level less likely to view China as a threat while the upper $51-75 \%$ in Indonesia showed the same result. Although high-income individuals in the Philippines were more likely to view China negatively, individuals in the highest income level in and Indonesia, which are also low-income countries, were less likely to have negative perceptions of China than those in the lowest income level although the associations were not statistically significant. Besides, high-income individuals from high-income countries such as Japan and South Korea should have shown less negative attitudes toward China which is a relatively capitalscarce and labor-abundant country. However, attitudes of individuals from those countries did not show any statistically significant associations with their income level. In short, individuals' income level showed inconsistent results, providing little empirical support for the Stolper-Samuelson theorem.

Meanwhile, the perception of China's economic growth had shown relatively consistent results in different country-specific models. Japan was the only country which the positive attitude of China's economic growth did not show statistically significant association with viewing China as a threat, although that association was still negative. Also, individuals in Indonesia, Japan, and Thailand who were "somewhat" or "very concerned" that territorial disputes between China and its neighbors might lead to a militarized dispute were more likely to view China as a threat than those who are "not at all concerned." Also, 
individuals who think the US is the most dependable ally of their country were more likely to view China as a threat than those who believe otherwise, except in Indonesia. These results show that non-economies factors also have significant impacts on individuals' attitudes toward China, providing evidence that these factors should be controlled to measure how economic impact affects their views of China.

Since little empirical support was found for the Stolper-Samuelson theorem, in the next step, the dependent variable was replaced with whether individuals view China unfavorably or not (Q15b of the Pew Research Center survey). The replacement was based on the consideration that trade might shape individuals' attitudes toward other countries, either positively or negatively, but not enough to affect individuals' perception of "threat." Whether individuals perceive other countries as a threat or not might be affected more by concerns over their country's national security than their economic interests.

To continue using the logistic regression models, the responses were simplified into two categories instead of four. A value of one is assigned to those who answered that they have "very unfavorable" and "somewhat unfavorable" opinion of China while a value of zero is assigned to those have "somewhat favorable" and "very favorable" view of China.

Table 3. Q15b. Please tell me if you have a very favorable, somewhat favorable, somewhat unfavorable or very unfavorable opinion of (China)?

\begin{tabular}{lllllll}
\hline & $\begin{array}{l}\text { Very } \\
\text { favorable(\%) }\end{array}$ & $\begin{array}{l}\text { Somewhat } \\
\text { favorable(\%) }\end{array}$ & $\begin{array}{l}\text { Somewhat } \\
\text { unfavorable } \\
(\%)\end{array}$ & $\begin{array}{l}\text { Very } \\
\text { unfavorable } \\
(\%)\end{array}$ & $\begin{array}{l}\text { Don't know/ } \\
\text { Refused (\%) }\end{array}$ & $\mathbf{n}$ \\
\hline Indonesia & 14.60 & 51.80 & 23.80 & 2.10 & 7.70 & 1,000 \\
Japan & 0.70 & 6.20 & 38.60 & 52.00 & 2.50 & 1,000 \\
Malaysia & 12.67 & 60.79 & 14.16 & 2.77 & 9.61 & 1,010 \\
South Korea & 6.15 & 32.54 & 35.32 & 22.72 & 3.28 & 1,009 \\
Thailand & 2.68 & 53.62 & 36.87 & 5.25 & 1.59 & 1,000 \\
The Philippines & 15.90 & 56.00 & 15.10 & 2.20 & 10.80 & 1,000 \\
\hline
\end{tabular}

As shown in Table 3, the percentages of having unfavorable opinions of China varied widely among countries, ranging from $16.93 \%$ (Malaysia) to $90.6 \%$ (Japan). While $17.30 \%$ of Filipinos, $25.90 \%$ of Indonesians, and $42.12 \%$ of Thais viewed China unfavorably, the percentage was 58.04 among South Koreans. 
Effects of International Trade on East and Southeast Asians' Views of China $\mid 177$

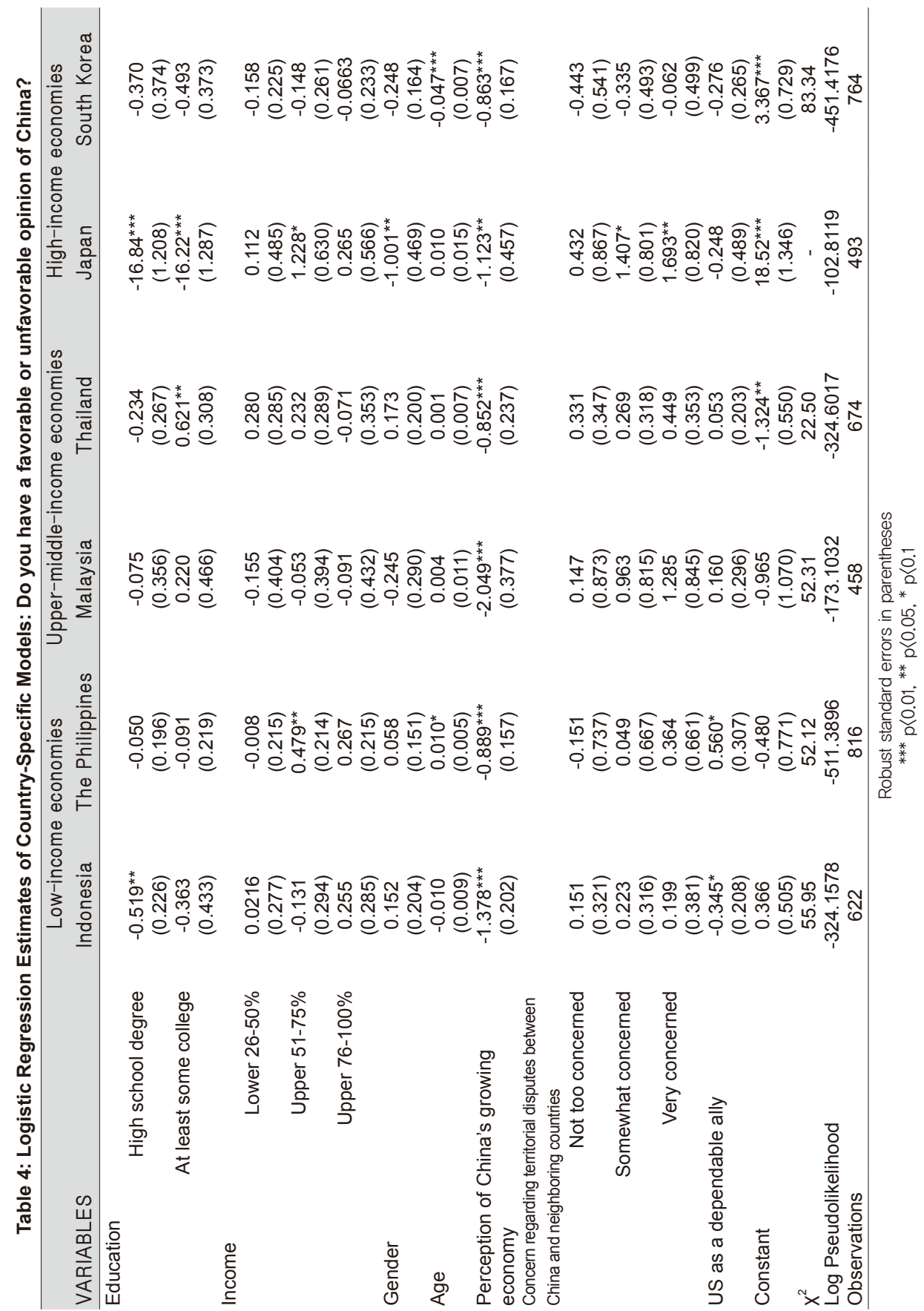


Table 4 shows the empirical results of whether individuals view China unfavorably or not depending on whether they are likely to be winners or losers of trade with China. Interestingly, in Japan, individuals with high school or at least some college education were less likely to have unfavorable opinions of China than those who are less educated ( $\mathrm{p}<0.01$ for both categories). Although the finding supports the Stolper-Samuelson theorem, the result should be interpreted with caution since the percentage of Japanese who have a favorable view of China is extremely low compared to other countries, as shown in Table 3. On the other hand, high-skilled Thais were more likely to have an unfavorable opinion of China than the low-skilled $(\mathrm{p}<0.05)$ - a finding that supports the theorem considering the lower average monthly wages in Thailand than in China, as shown above. However, in other countries, those who are likely to be the winners of trade with China were not particularly likely to have a favorable opinion of China, showing little empirical support for the Stolper-Samuelson theorem. Meanwhile, respondents with a positive perception of China's growing economy were less likely to view China unfavorably in all six countries, showing the most consistent results.

Since there is little support for the Stolper-Samuelson theorem, it will be replaced with individuals' attitudes regarding international trade to continue the analysis further. The expected results are that individuals' positive views of trade with other countries - growing trade with other countries is a good thing to a respondent's country (Q27 of the Pew Research Center survey), trade increases wages (Q28), and trade creates jobs (Q29) - will reduce the likelihood of viewing China as a threat. 
Effects of International Trade on East and Southeast Asians' Views of China 179

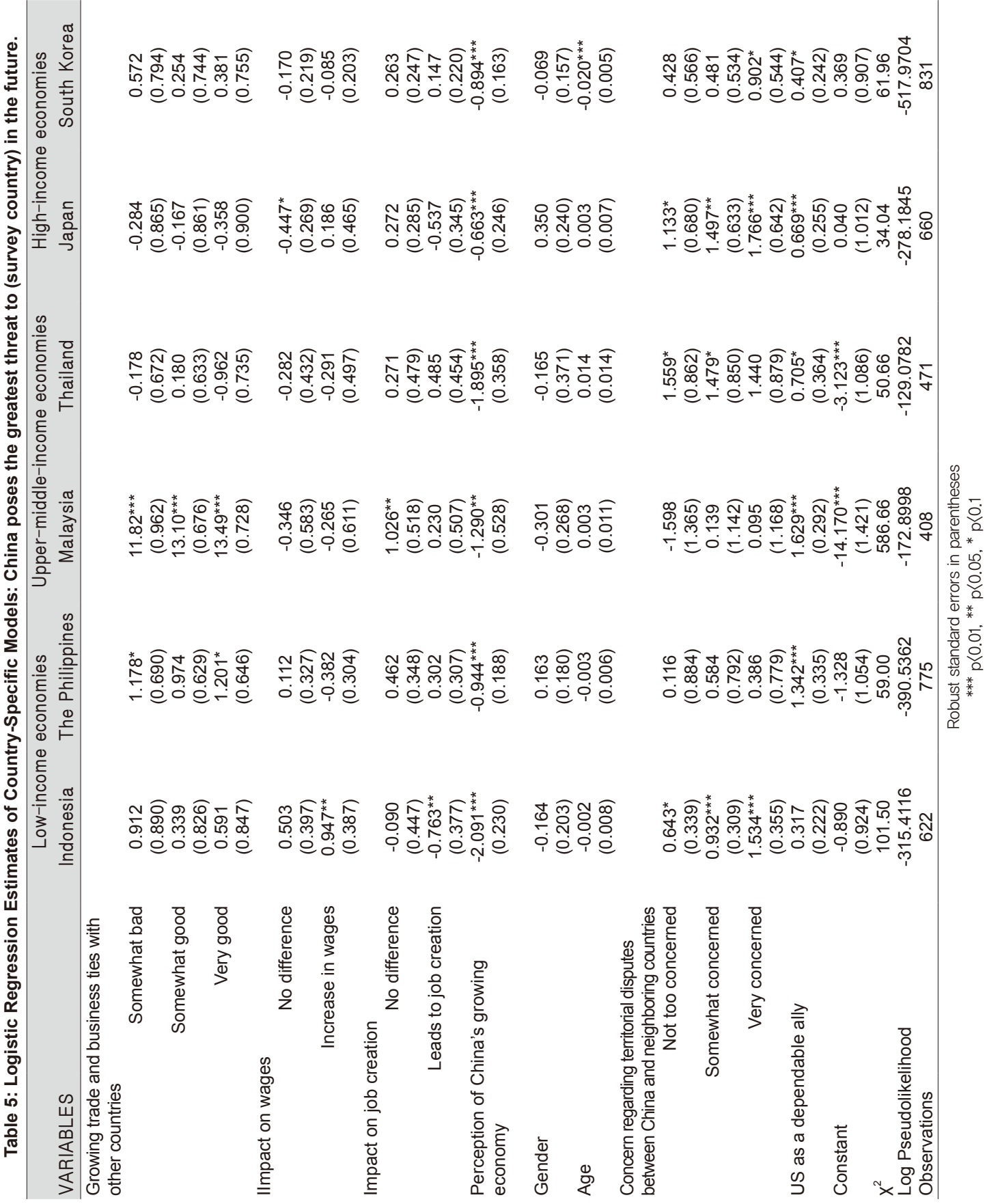




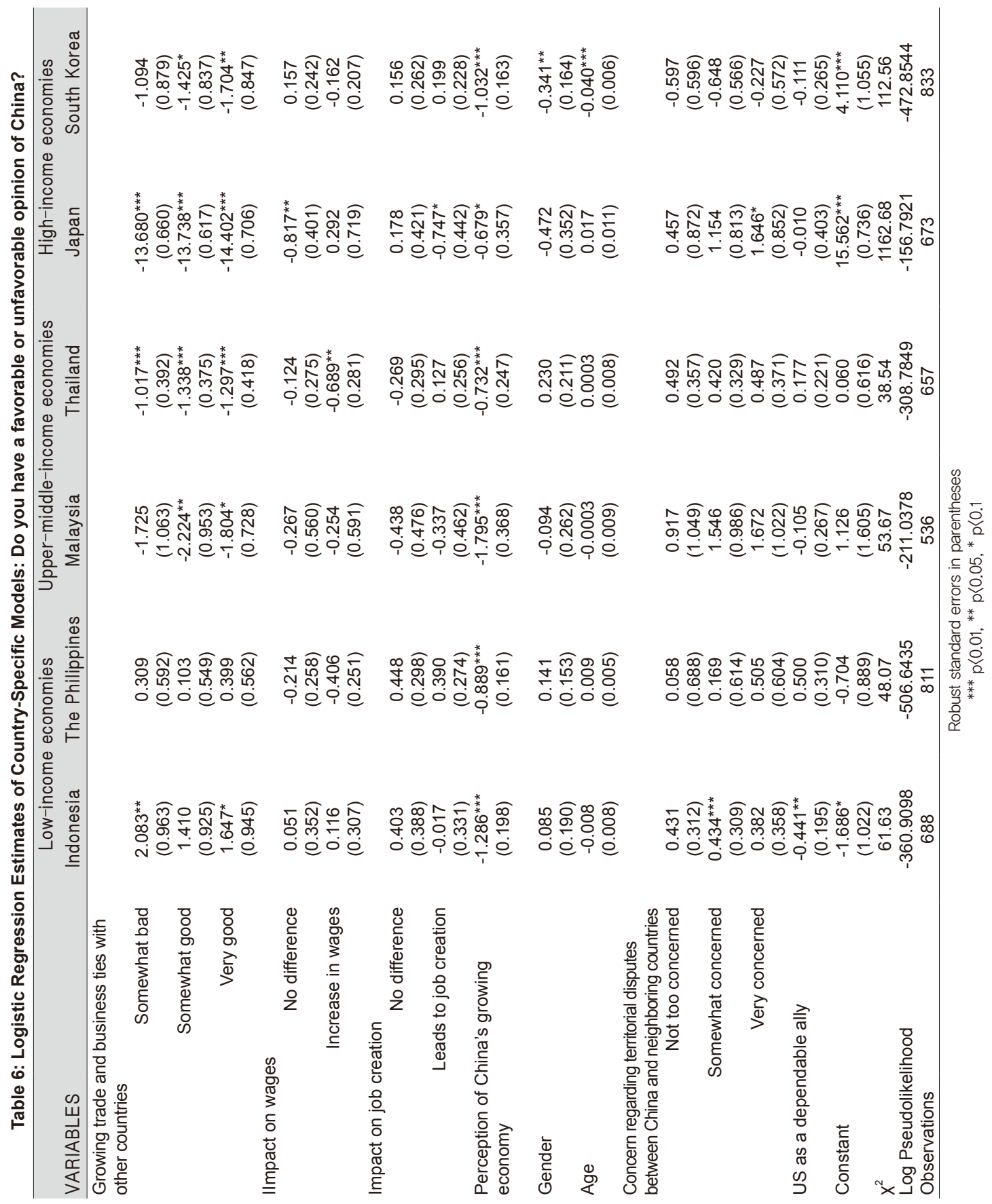


As shown in the country-specific models in Table 5, the results are not consistent. Still, individuals who think growing trade and business ties with other countries are "very good" for their country were more likely to view China as a threat than those who said "very bad," in the Philippines, and Malaysia ( $\mathrm{p}<0.05, \mathrm{p}<0.1$, and $\mathrm{p}<0.01$, respectively). However, in other countries, the positive views of growing trade and business ties with other countries did not show any statistically significant associations with individuals viewing China as not a threat. Meanwhile, the positive perception of China's economic growth was negatively associated with viewing China as a threat in all six countries.

When the dependent variable is whether individuals have favorable or unfavorable opinions of China, as in Table 6, those who think growing trade and business ties with other countries are "very good" for their country were less likely to view China unfavorably than those who said "very bad," in both highincome and upper-middle-income economies but not in low-income economies. In other words, while individuals with positive opinions of international trade ties were more likely to have favorable views of China, that does not necessarily indicate that those individuals do not regard China as a threat to their country. Meanwhile, like the results in the previous tables, the positive perception of China's economic growth was negatively associated with viewing China unfavorably in all six countries.

In summary, the findings obtained from Table 2, 4, 5, and 6 indicate that positive views regarding international trade ties affect individuals to have favorable opinions of China (especially in upper-middle-income and highincome economies) but, at the same time, the educated individuals in East and Southeast Asia are still more likely to regard China as a threat to their country (except in Indonesia) than the less educated regardless of whether they are expected to be the winners of trade with China or not.

\section{CONCLUSION}

The main question of this article is how trade influences individuals' views of China as a threat or not. This question is derived from the commercial peace argument that economic ties deter conflicts and promote peace between states. This article applied the commercial peace argument to the individual level to test whether individuals who are expected to benefit from trade with China are more likely to have positive views of China than those who lose.

The major findings of this article are that highly educated individuals were more likely to perceive China as a threat to their country, regardless of whether 
they are from low-income, upper-middle-income, or high-income countries (except in Indonesia as mentioned above). Even those high-skilled workers in Japan and South Korea (high-income economies), who are predicted to be the beneficiaries of trade with China, showed negative views of China than the less skilled. Regarding individuals' income level, it had little effect on their views of China. Thus, there is little empirical support for the Stolper-Samuelson theorem. On the other hand, positive attitudes toward trade and business ties with other countries reduced the likelihood of having unfavorable opinions of China (in the upper-middle-income and high-income countries). However, it did not reduce the likelihood of viewing China as a threat.

These results indicate that, while support for international trade fosters positive opinions of China, it might not be enough to completely prevent individuals from regarding China as a threat to their country in the future. In other words, whether individuals perceive other countries as a threat or not seems to be affected more by concerns over their country's national security than their economic interests. These findings suggest that there is not enough evidence to argue that there is a potential for achieving commercial peace between China and its democratic neighbors at this stage.

Only those who viewed China's economic growth as a good thing to their country were less likely view China as a threat and have unfavorable opinions at the same time. However, this result should be interpreted with caution since it is unclear whether a positive attitude of China leads to a positive perception of China's economic growth or whether the causality runs in the other direction.

As shown above, in contrast to the expectation that educated individuals in high-income countries will have positive views of China, this article showed that more educated individuals are more likely to view China as a threat, regardless of their country's relative factor endowment. Thus, more study should be conducted on what causes educated Asians to be more concerned about the rise of China than the less educated.

It is also necessary to be aware that the situation in Asia is changing rapidly. While China has been regarded as a labor-abundant country thus far, there are signs that China has started to move up the value chain, producing hightechnology goods such as smartphones rather than remaining as a center of processing trade (Mathai et al. 2016). In other words, China might not be labeled simply as a labor-abundant country in the near future. Thus, the change in China's trade structure could affect individuals' views toward China in the future, particularly those in the high-income countries.

Furthermore, although this article showed that individuals' educational attainment, perception of trade and business ties with other countries, and 
perception of China's economic growth can have impacts on their attitudes of China, further study is necessary to explore how much public opinion shapes or at least constrains foreign policy decisions of the governments, particularly in democracies and in Asian countries.

Meanwhile, not all China's neighbors are democracies. According to the Polity IV project, countries like Vietnam is not a democracy. Meanwhile, there is an ongoing dispute over the South China Sea (Ives 2017). In this case, it is unclear whether there is a possibility that individual Vietnamese' educational attainment or their perception of trade with other countries could affect their government's foreign policy decisions toward China. Therefore, further study will be necessary to know how China's economic growth will impact the relationship between China and its non-democratic neighbors.

\section{REFERENCES}

Al-Rodhan, Khalid. 2007. "A critique of the China threat theory: a systematic analysis.” Asian Perspective 31(3), 41-66.

Baker, Andy. 2005. "Who Wants to Globalize? Consumer Tastes and Labor Markets in a Theory of Trade Policy Beliefs." American Journal of Political Science 49(4), 924-938.

Beaulieu, Eugene, Ravindra Yatawara and Wei Guo Wang. 2005. "Who Supports Free Trade in Latin America?” World Economy 28, 941-958.

Chiang, Min-Hua. 2013. "The Potential of China-Japan-South Korea Free Trade Agreement.” East Asia 30, 199-216.

Chung, Jae Ho. 2009/2010. "East Asia Responds to the Rise of China: Patterns and Variations." Pacific Affairs 82(4), 657-675.

Direction of Trade Statistics (DOTS) n.d. IMF eLibrary Data. Accessed at:

http://data.imf.org/?sk=9D6028D 4-F14A-464C-A2 F 259B2CD424B85 (January 12, 2017).

Fordham, Benjamin O. 1998. "Partisanship, Macroeconomic Policy, and U.S. Uses of Force, 1949-1994." Journal of Conflict Resolution 42(4), 418439.

Fordham, Benjamin O. and Katja B Kleinberg. 2011. "International trade and US relations with China." Foreign Policy Analysis 7, 217-236.

. 2012. "How Can Economic Interests Influence Support for Free Trade?" International Organization 66(2), 311-328.

Fravel, M Taylor. 2011. "China's Strategy in the South China Sea." Contemporary Southeast Asia: A Journal of International and 
Strategic affairs 33(3), 292-319.

Frieden, Jeffery A. and Rogowski Ronald. 1996. "The impact of the international economy on national policies: An analytical overview." In Robert O. Keohane and Helen V. Milner eds., Internationalization and domestic politics, Cambridge, Cambridge University Press, 25-48.

Gartzke, Erik. 2003. "The Classical Liberals Were Just Lucky: A Few Thoughts about Interdependence and Peace.” In Edward D. Mansfield and Brian M. Pollins eds., Economic Interdependence and International Conflict: New Perspectives on an Enduring Debate. Ann Arbor: University of Michigan Press, 96-110.

Gelpi, Christopher, and Joseph M. Grieco. 2003. "Economic Interdependence, the Democratic State, and the Liberal Peace." In Edward D. Mansfield and Brian M. Pollins eds., Economic Interdependence and International Conflict: New Perspectives on an Enduring Debate. Ann Arbor: University of Michigan Press, 44-59.

Hainmueller, Jens, and Michael J Hiscox. 2006. "Learning to love globalization: Education and individual attitudes toward international trade." International Organization 6o(2), 469-498.

Hegre, Håvard, John Oneal and Bruce Russett. 2010. "Trade does promote peace: New simultaneous estimates of the reciprocal effects of trade and conflict." Journal of Peace Research 47(6), 763-774.

ILO. 2014. "ILO Regional Office for Asia and the Pacific." Global Wage Report 2014/15: Asia and the Pacific Supplement. International Labor Organization. Accessed at https://www.ilo.org/wcmsp5/groups/ public/---asia/---ro-bangkok/---sro-bangkok/documents/publication/ wcms_325219.pdf (July 14, 2018).

Ives, Mike. 2017. "China Cancels Military Meeting With Vietnam Over Territorial Dispute." New York Times (June 21). Accessed at: https:// www.nytimes.com/2017/06/21/world/asia/china-vietnam-southchina-sea.html?_r=o (July 17, 2017).

Kang, David. 2005. "Why China's rise will be peaceful: hierarchy and stability in the East Asian Region." Perspectives on Politics 3(3), 551-554.

Kleinberg, Katja B. and Benjamin O Fordham. 2010. "Trade and Foreign Policy Attitudes.” Journal of Conflict Resolution 54(5), 687-714.

Lall, Sanjaya, and Manuel Albaladejo. 2004. "China's Competitive Performance: A Threat to East Asian Manufactured Exports?” World Development 32(9), 1441-1466.

Levy, Jack S. 2003. "Economic Interdependence, Opportunity Costs, and Peace." In Edward Mansfield and Brian M Pollins eds., Economic 
Interdependence and International Conflict: New Perspectives on an Enduring Debate. Ann Arbor: University of Michigan Press, 127-147.

Marshall, Monty G. and Ted R Gurr. n.d. "Polity IV Individual Country Regime Trends, 1946-2013." Polity IV Project: Political Regime Characteristics and Transitions, 180o-2013. Accessed at http://www.systemicpeace. org/polity/polity4.htm (January 24, 2017).

Mathai, Koshy, Geoff Gottlieb, Gee Hee Hong, Sung Eun Jung, Jochen Schmittmann, and Jiangyan Yu. 2016. "China's Changing Trade and the Implications for the CLMV Economies." International Monetary Fund Asia and Pacific Department. Accessed at https://www.imf.org/ external/pubs/ft/dp/2016/apd1601.pdf (July 16, 2017).

Mayda, Anna M. and Dani Rodrik. 2005. "Why are some people (and countries) more protectionist than others?" European Economic Review 49, 1393-1430.

McLean, Elana V. and Taehee Whang. 2014. "Designing Foreign Policy: Voters, Special Interest Groups, and Economic Sanctions.” Journal of Peace Research 51(5), 589-602.

Mearsheimer. John J. 2006. "China's unpeaceful rise." Current History 105, 160-162.

. 2010. "The Gathering Storm: China's Challenge to US Power in Asia." The Chinese Journal of International Politics 3(4), 381-396.

Oneal, John R. and Bruce M. Russett. 1997. "The Classical Liberals Were Right: Democracy, Interdependence, and Conflict, 1950-1985.” International Studies Quarterly 41(2), 267-294.

Oneal, John R. 2003. "Empirical Support for the Liberal Peace." In Edward D. Mansfield and Bruce M. Pollins eds., Economic Interdependence and International Conflict: New Perspectives on an Enduring Debate. Ann Arbor: University of Michigan Press, 189-206.

Ozler, Sule. 2000. "Export orientation and female share of employment: Evidence from Turkey.” World Development 28(7), 1239-1248.

Page, Benjamin I. and Robert Y. Shapiro. 1983. "Effects of Public Opinion on Policy." American Political Science Review 77(1): 175-190. . 1992. The Rational Public: Fifty Years of Trend in American Policy Preferences. Chicago: University of Chicago Press.

Papayoanou, Paul A. 1996. "Interdependence, Institutions, and the Balance of Power: Britain, Germany, and World War I." International Security 20(4), 42-76.

Pew Global Attitudes \& Trends Spring 2014 Survey Data. 2014. Pew Research Center. Accessed at http://www.pewglobal.org/category/datasets/ 
(August 15, 2017).

Rowan, Joshua P. 2005. "The U.S.-Japan Alliance, ASEAN, and the South China Sea Dispute." Asian Survey 45(3), 414-436.

Roy, Denny. 1994. "Hegemon on the Horizon China's Threat to East Asian Security." International Security 19(1), 149-168.

. 2005. "Southeast Asia and China: Balancing or Bandwagoning?" Contemporary Southeast Asia 27(2), 305-322.

Shambaugh, David. 2005. "China engages Asia: reshaping the regional order." International Security 29(3), 64-99.

Simmons, Beth. 2003. "Pax Mercatoria and the Theory of the State." In Edward D. Mansfield and Brian M Pollins eds., Economic Interdependence and International Conflict: New Perspectives on an Enduring Debate. Ann Arbor: University of Michigan Press, 31-43.

Sobel, Richard. 2001. The Impact of Public Opinion on U.S. Foreign Policy since Vietnam. Oxford: Oxford University Press.

Storey, Ian J. 1999. "Creeping Assertiveness: China, the Philippines and the South China Sea Dispute.” Contemporary Southeast Asia 21(1), 95-118.

Tamkin, Emily. 2016. "Japan Talks Tough on Senkaku Islands Dispute with China." Foreign Policy (December 21). Accessed at: http:// foreignpolicy.com/2016/12/21/japan-talks-tough-on-senkaku-islandsdispute-with-china/ (January 20, 2017).

The Economist. 2013. "Troubled skies over troubled waters." The Economist (November 25). Accessed at http://www.economist.com/blogs/ analects/2013/11/east-china-sea-dispute (January 20, 2017). . 2015. "A Tightening Grip." The Economist(May 12). Accessed at https://www.economist.com/news/briefing/21646180-rising-chinesewages-will-only-strengthen-asias-hold-manufacturing-tightening-grip (July 12, 2017).

Tiezzi, Shannon. 2015. "Is China Ready to Solve One of Its Maritime Disputes?" The Diplomat (November 7). Accessed at http:// thediplomat.com/2015/11/is-china-ready-to-solve-one-of-itsmaritime-disputes/ (January 19, 2017).

Tversky, Amos, and Daniel Kahneman. 1983. "Extensional Versus Intuitive Reasoning: The Conjunction Fallacy in Probability Judgement." Psychological Review 90(4), 293-315.

UN Comtrade Database. n.d. United Nations Statistics Division. Accessed at https://comtrade.un.org/data/ (December 17, 2017).

World Bank Country and Lending Groups. n.d. The World Bank. Accessed at https://datahelpdesk.worldbank.org/knowledgebase/articles/906519- 
world-bank-country-and-lending-groups (March 3, 2018).

Xing, Yuqing. 2011. "China's High-tech Exports: Myth and Reality." GRIPS Discussion Paper 11-05, National Graduate Institute for Policy Studies, June 2011.

Yahuda, Michael. 2013. "China's New Assertiveness in the South China Sea." Journal of Contemporary China 22(81), 446-459.

[Received May 28, 2019; Revised Jun 18, 2019; Accepted Jul 24, 2019] 